\title{
(re) Findings: \\ Discovery and memory in the architecture and legacy of surrealism
}

\author{
Michael Chapman
}

It is in discovery alone, that one recognises the marvellous headlong rush of desire. It alone can enlarge the universe, causing it to relinquish some of its opacity, letting us discover its extraordinary capacities for reserve, proportionate to the innumerable needs of the spirit. Daily life abounds in exactly this sort of small discovery ... You only have to know how to get along in the labyrinth. (Breton 1987: 15-16)

Historicity, specifically the construction of images and their subsequent remembering, has a special relevance for the endeavours of Dada and surrealism, two movements which sought to reconstruct the everyday through a disassembly of images and their values. The architecture of the city was an important part of this process. It was celebrated by the surrealists for its residual qualities that not only evoked historical time but spatial and lived experience more generally. While studies of architecture and surrealism have focussed, to a large extent, on the "objects" that they selected to substitute for buildings, there is an equally rich counter-current within surrealism that used memory and the found object as a strategy to dismantle the homogenising forces of modernist architecture. Within this is a re-discovery of the historical trace and its power as a polemical tool in the construction of images and their dissemination.

This paper investigates the role of the objet trouvé within the activities of the avant-garde, with an emphasis on the theoretical discourse that was attached to surrealism in the 1970s. The objet trouvé-literally "found object"-became a fascination for both Dada and surrealism in the 1920s. Both movements used the discovery of objects (and the associated psychological displacement) to challenge bourgeois conventions of the art object and contemporary expectations of lived experience. In the 1970s there was, for the first time, a dedicated discourse on avant-garde practice which set out to diagnose the specific practices of the historical avant-garde and the philosophical motivations underpinning them. If modernism was characterised by the autonomy of the artistic object in this discourse, avant-garde practices in this period were defined by the conflation of art and life in artistic production and the rejection of aesthetic categories more generally. In this sense, the avant-garde can be seen as a distinct trajectory from modernism: a fact that has been made explicit in the theoretical positions of both Hilde Heynen (1999) and Andreas Huyssen (1986), amongst others.

The "discovery" of images is an important aspect of this discourse and central to the avant-garde project. There are numerous examples of the way that "images" of the city function in the reconstruction of memory. They are replete in surrealist fiction. The "Tour Saint Jacques", for instance, becomes the "psychological fulcrum” (Krauss 1981: 33-34) in Breton's L'Amour Fou, where the poet's fear of an unknown woman turns to lust. The tower also functions to trigger memories of an earlier poem that the poet had forgotten-reignited by the site and his pursuit of romance across it. Interestingly, an iconic photograph by Brassai records (or reconstructs) this "moment", and was published with the text at the time. The confluence of words and images that is constructed in L'Amour Fou was replicated 
1 The exception is Kurt Schwitters' Merzbau, which has attracted a large amount of scholarly interest in the last two decades, especially in relation to its avant-garde credentials. See, for instance: Macarthur 2010: 283-300; Burns Gamard 2000; Dietrich 1991: 14.

2 Le Corbusier's house for Beistegui or Adolf Loos's house for Tristan Tzara are two clear examples (Frampton 1978: 138; Gorlin 1982: 58-60).

3 Benjamin's quote from Passagenwerk linking Breton and Le Corbusier captured this: "To embrace Breton and Le Corbusier ... would be to draw the spirit of contemporary France like a bow which strikes with knowledge to the heart of the present." (Benjamin quoted in Vidler 1992: 151; Vidler 2003: 12.) throughout the surrealist journals, supplementing the texts of the primary poets and artists with visual proof of the experience. One characteristic of this visual material is the continual presence of architecture and the city as the backdrop to surrealist experience and, inadvertently, the reconstruction of surrealist history.

The exact nature of an architecture of the historical avant-garde remains contested, especially in relation to Dada and surrealism where, despite the scholarly interest in the topic, there is a virtual consensus that architecture was not their primary concern (Vesely 1978: 138). Numerous authors retracing the connections between architecture and the historical avant-gardes have lamented the failure of Dada and surrealism to produce architecture, ${ }^{1}$ or have focussed on architectural objects that are historically (rather than definitively) surrealist. ${ }^{2}$ As early as 1978 Vesely had argued that the surrealists were "not particularly interested" (1978: 138) in architecture and by 2010 had concluded that architecture "did not become an integral part of surrealist endeavour" (2010: 31). Frampton, in Vesely's edited volume on the subject, had maintained that "the surreal in architecture does not exist" (Frampton 1978: 98), while Thomas Mical, in his later volume on the same subject, argued that architecture is the "unfulfilled promise of surrealist thought" (2005: 2). Even Anthony Vidler conceded that "architecture did not apparently play an extensive role in surrealist concerns” (2003: 1). The surrealists' preoccupation with the work of Cheval, Gaudi and even Guimard has further tended to narrow investigations in this field, providing a stylistic model that the philosophical concerns of Dada and surrealism can be accommodated within but without any deeper scrutiny of the architectural possibilities that lie beyond it.

Given this, there is a failure in the scholarship of Dada and surrealism to place an appropriate emphasis on negation in avant-garde activities, especially as it relates to architecture and the construction of images. Vesely acknowledges the role of negation in Dada and, like many scholars of art history, sees Duchamp as a pivotal figure on this path, instrumental for separating the independent trajectories of modernism and the avant-garde (1978: 88). Evoking Walter Benjamin, ${ }^{3}$ Vesely quotes Breton, who identifies a "line of demarcation between the two [positive and negative] spirits that will tend to oppose one another more and more in the very heart of the modern spirit" (Breton 1978: 14). However, for Vesely, negation functioned in a productive capacity in surrealism, transforming the conventions of life through imagination and experience. Vesely argues several decades later that: "the relation of surrealists to architecture was limited almost exclusively to the discovery of buildings and places appreciated as a result of objective chance (objet trouvé)" (2010: 40). This aspect of Vesely's argument has a particular overlap with aesthetic theories of the avant-garde, and particularly those of the Frankfurt School.

It is clear that the historical avant-garde already understood and articulated the psychoanalytical aspects of the objet trouvé and its transformative qualities. In 1905, Freud had written in his Three Essays on Sexuality that the "finding of an object is in fact a refinding of it" (255) and, in the 1930s, Breton had compared the act of discovery to the transformative experience of the dream (1987: 32). While Vesely acknowledges the role that discovery played in surrealist attitudes towards architecture, he neglects the transformative nature of this discovery, which indelibly altered the avant-gardiste work of art and shifted the emphasis onto an unprecedented spatiality in creative production. Given this, it is productive to further explore the role that architecture plays within broader theories of avant-garde production, with a particular view towards the role of memory and image in the architectural fascinations of Dada and surrealism. 


\section{Theories of the avant-garde}

Peter Bürger's argument in Theory of the Avant-Garde (1984) has not attained much traction in the scholarship of architectural history, despite its ready adaptability to architecture. Despite this, Bürger's short work is instructive for the scholarship of architectural history as it promotes an investigation of the historical categories of architectural production, rather than the aesthetic categories of architectural form. If, as Bürger asserts, the avant-gardiste work of art negated the aesthetic "production" of art, then it followed that the avant-gardiste work of architecture was, similarly, not linked to the production of architecture but to its rediscovery or negation. As the avant-garde discovered the objet trouvé and presented it as an affront to bourgeois aesthetics, Dada and surrealism drew upon a forgotten architecture, which was repackaged as an affront to the aesthetics of modernism, retaining the baggage of the nineteenth century, while simultaneously reconnecting the avant-garde with the experiential stimulation that they craved. ${ }^{4}$

Bürger had a particular fascination with surrealism. While his book is relatively brief, Bürger cites the works of Marcel Duchamp, the collages of early Berlin Dada and the evolution of montage through the lens of surrealism as the primary evidence in support of his theory. Of the limited illustrated examples in Theory of the Avant-Garde, Dada and surrealism (including Duchamp, Magritte and Heartfield) account for half. While Bürger reads surrealism primarily through the genre of surrealist fiction, ${ }^{5}$ there is an emphasis on the objet trouvé that permeates his work and analysis. This is also a recurring theme in the English language reception of Bürger's work, and especially in the investigations of the Octoberist critics. Architectural space is a perennial theme within this, as the dissolution of medium is made to intersect with a cultural "spatiality" that characterises the most recent reworkings of Dada and surrealist practice. Rosalind Krauss, for instance, has argued for a spatiality in the work of Duchamp which is antivisual in nature (1994) and Hal Foster has drawn attention to the outmoded as a spatial model through which to reposition surrealist practice (1995: 157-191; 2002a: 195-196; 2002b: 138-139). In both readings, architecture exists as a found context against which creative acts and works are projected and reconstructed.

As early as 1929 Walter Benjamin had argued that surrealism was an avant-garde not of the new, but of the old, radically repositioning the outmoded objects of everyday life in opposition to technology and the rampant consumer fetishism that absorbed increasing percentages of the visual landscape (1978: 192). For Benjamin, architecture-understood primarily through the work of Giedion (1995) - was a critical but overlooked aspect of surrealism that had been instrumental in articulating its radicalised relationship with history (see Mertins 1999: 196-221). Giedion (1995) returned to this theme after Benjamin's death and, in his postwar discussion of the collages of Ernst (whom he knew personally), Giedion concluded that: "drops from the nineteenth century flowed in his veins" (1969: 361). This outmoded revolutionary "nihilism" is a significant theme in the work of Bürger who demonstrates that Adorno's (1997) theory of modern art has an overdependence on the category of the new. ${ }^{6}$ Historically, as in the case of Greenberg (1971), ${ }^{7}$ the new was entwined with the concerns of the avant-garde and central to its definition and interpretation. Negating the influence or value of the outmoded, Adorno's 1956 essay on surrealism had argued that it was "paradoxical for something modern, already under the spell of ... mass-production, to have any history at all” (1991: 88).

For Bürger, however, the new was not a characteristic of modernism but a prerequisite of all historical epochs. and it was of little use in explaining the tactics of the historical avant-garde as they were radically outside of the established
4 In this regard, Jane Allison (2010: 21) refers to a maison trouvée as a surrealist trope.

5 Focussing primarily on the literary works of early surrealism, Bürger's prior book (from 1971) is, four decades later, still awaiting translation into English (Bürger 1971). Subsequent works by Bürger have addressed surrealism and Dada directly and with some authority (1985-86; 1992; 2002).

6 Bürger is primarily concerned with the passage at the start of Aesthetic theory where Adorno explains the new as a dialectical opposition to tradition (Adorno 1997: 45). In an extended analysis of Adorno's theory in relationship to the avant-garde, Peter Osborne (1989: 23-48) has argued that Adorno constructs a theory of modernism divided between dissonance and the new.

7 See, for instance, the contemporaneous "Counter avant-garde" (Greenberg 1971: 1619). The focus of both Greenberg and Michael Fried (1982: 217-234) was "presentness" which was indelibly entwined with the new. 
traditions against which the new could be evaluated. Poggioli makes a similar argument, several years earlier than Bürger. In the final section of his own Theory of the Avant-Garde, Poggioli argues that: "[w]hat characterises avant-garde art is the myth of the new ... There is no great difference in the concrete concept that the ancients and the moderns have of the new; but there is an enormous difference in their respective evaluations of it” (1968: 214). Pre-empting Bürger's position, Poggioli concludes that: "nothing is more new and modern than the modern cult of the new" (214).

By placing unprecedented importance on the sublation of art and life as an avantgardiste preoccupation, Bürger inadvertently provides the dialectic through which a theory of architecture in the historical avant-garde can be established. Architecture, as the predominant frame of social praxis, is connected to art not as art, but as a fragment of reality that becomes a recurring strategy of both freedom and constraint. The Dada assault on the institution of art was not simply a critique of aesthetic production, but an exhibition of the architecture in which art was displayed, as well as its spatial operations and prejudices. Architecture was interrogated for its attached "bourgeois" values in some contexts as much as for its social and functional symbolism in others.

The systematic negations of Dada and surrealism challenged the autonomy of the architectural object but at the same time embraced the experiential and symbolic characteristics of nineteenth-century commerce, allowing Habermas to argue that the sublation of art and life that the avant-garde intended was ultimately ineffective due to the limited sphere in which its influence was felt. Referencing the work of Bürger, Habermas asks whether the "failure of the surrealist rebellion" is symptomatic of a "farewell to modernity" and equally a transition towards postmodernity (1981: 11). The work of Habermas is centred around a basic faith in the idea and implementation of modernism and the modern project, characterised by the articulation of independent spheres-science, art and morality-which are, for the first time, isolated and "autonomous". In Habermas's critique (1981: 11), he argues that the activities of the avant-garde, while radical, were only ever directed at one of these spheres-the sphere of art-and as a result their impact would never amount to a universal collapse, but purely to the collapse of this one distinct field. This is contrary to the way that the surrealists saw their activities, especially in regard to architecture and the city.

\section{Architecture and life}

The argument presented here is that for the surrealists, architecture functioned as a contextual backdrop to the praxis of life. Operating outside the concerns of both aesthetics and the institution of art, architectural space was deployed for its oppositional relationship to these categories and primarily in the visual frameworks of collage, montage, film and photography. There is no doubt that these categories - defined to a large extent by the stewardship of Breton and formalised in the scholarship of both Vesely and Bürger - are contested and imply an artificial harmony to the highly diverse activities of the avant-garde. Current scholarship, however, under-appreciates how architecture functions as a recurring motif in all these activities. Throughout the avant-garde's broad range of aesthetic production, architecture appears as an objet trouvé, used selectively (but strategically) to reconnect aesthetic practices with life processes. The emergence of these techniques, in the years immediately after the First World War, provides a critical moment in framing a theory of architecture within the avant-garde. This is indelibly entwined with the cultural history of the image. 
Bürger's writing on the tactics of Dada and surrealism (1984: 109n) places a specific emphasis on the time period that spans between the origins of Dada (primarily in the readymades of Duchamp) and the migration to early surrealism as the period in which the claims of avant-gardism were first formulated and pursued. This timeframe - characterised by the emergence of distinctive avant-garde techniques and especially those of collage and montage - was one of productive invention where the traditional strategies of artistic production were radically challenged. ${ }^{8}$ Contained in an extended footnote, Bürger provides an important passage that synthesises his theory and the extent to which Dada and surrealism are the principle examples of it. Bürger writes:

The concept of the historical avant-garde movements used here applies primarily to Dadaism and early surrealism ... A common feature of ... these movements is that they do not reject individual artistic techniques and procedures of earlier art but reject that art, in its entirety, thus bringing about a radical break with tradition. In their most extreme manifestations, their primary target is art as an institution as such as it has developed in bourgeois society. (1984: 109n)

Vesely, on the contrary, denies the relevance of the "avant-garde" period of surrealism in architecture, arguing that "Surrealism does not begin in 1919 or 1924 , but much earlier, in the romanticism of the nineteenth century and, to some extent, even earlier in the esoteric hermetic traditions of the Renaissance" (1978: 89). For Vesely, surrealism needs to be considered outside of the doctrines that were produced by "Surrealism" and its most prominent members ${ }^{9}$ and be regarded as a philosophical and psychological strategy for seeing the world, rather than a specified historical phenomenon. Vesely argues that:

... attempts to reduce surrealism to a set of principles and goals-such as automatism, objective chance, transformation of the world and life-do not reveal the primary goal of the movement: to reach an absolute point of reconciliation of dream and reality. (1978: 87)

At stake is the schism between the aesthetic direction of Breton (towards a tightly defined and strategically aligned movement) and the divergent directions of its individual members which challenged all forms of overriding theoretical dogma. Despite this, Vesely sees the relationship between Dada and surrealism as part of a historical framework, whereby the negative tactics of Dada were transformed, through surrealism, into positive affirmations of life. For Vesely, the nihilistic tendencies of Dada, which figure centrally in the dialectical approach of Bürger, ${ }^{10}$ predate the primary concerns of surrealism and are disconnected from the real world and the experience of life that structured much of surrealist doctrine. This is antithetical to Bürger's reading, which sees the negation of art process in Dada as the direct conflation of art and life (and the origins of avant-garde radicalism). As both authors acknowledge, there is a tension between the discourse of the 1920s and its often accidental and frequently conflicting practices.

Arguing for surrealism as a sublation of dream and reality, Vesely contends that architecture was not a primary concern of Dada and surrealism as it was "so much embedded in every-day life" (1978: 91). Vesely observes that "reality was always a bitter encounter for the surrealists" and that, while the mediums of poetry or painting could achieve this sublation in the viewer's consciousness, architecture was unable to transcend its status in the real world, marginalising its relevance as a disciplinary activity. However, this neglects the fact that architecture was
8 Dada and surrealism are, by nature, difficult historical paradigms. A number of the historiographical issues in relationship to surrealism are central to recent scholarship (Baker 2007: 25-64).

9 The capitalisation here refers to the Surrealism Movement, officially led by André Breton and whose membership is restricted to the signatories to the various manifestoes of Surrealism.

10 Bürger $(1984: 22,53,56)$ evokes Dada as the most extreme manifestation of the avantgarde on a number of occasions. 
11 After diagnosing the avant-garde tendency to conflate art and life, Bürger (1984: 50) also articulates the dangers of this process, including the loss of criticality that art assumes with the collapse of its autonomy.

12 A famous example occurs in Breton's "Surrealist situation of the object" (1972 259). Dali also launched a reclamation of art nouveau architecture in opposition to modernism (Fanés 2007: 90-91; 162-164).

13 The emphasis on Bataille in contemporary readings of surrealism is testament to this. His anachronistic position, celebrated disproportionately in French poststructuralism and American critical theory, is as much a critique of modernism as a radical attack on morality (Spiteri 2009 : 1-27: Sulieman 1994:61-79.

14 First raised in his influential "Modernity: An unfinished project" (translated as "Modernity and postmodernity"), the paper has been the source of ongoing debates concerning modernism and the avant-garde (Passerin d'Entréves \& Ben-Habin 1997; Bürger 1985-1986: 5-33). a powerful and recurring "dream-image" within surrealism and it provided an important and structural role in organising the visual fantasies of the key proponents. This is far more significant than any of the built structures which are the legacy of much of the scholarship in the field.

While accepting the formative emphasis that Vesely places on reality in Dada and surrealism, there are a number of aspects of this position that are underdeveloped. By focussing on architecture as a solitary medium-independent of drawing, painting, the readymade or literature-Vesely imbues architecture with a privileged (built) status that was far from representative of the merging of experimental strategies in the period or, for that matter, the evolution of visual techniques where architecture was fundamentally entwined. In this sense, Bürger's work is critical, as it not only stresses the dissolution of autonomous techniques (and their merging into hybrid and fragmented forms of each other) but it also proselytises the sublation of art and life through the avant-gardiste work of art, demonstrating that "reality" and "functionalism" were specific strategies of the avant-garde assault on bourgeois aesthetic conventions. ${ }^{11}$

While Vesely is sceptical about the role of architecture in the formation of explicitly avant-garde aesthetic strategies, he does illustrate the importance of the readymade object to the historical relationship between architecture and surrealism. Vesely demonstrates that the readymade provided a bridge between the negations of Dada and their positive redemption in the surrealist object and functioned as "[a reminder] of the link which once existed between the spirit of Dada and surrealism, between negation and [the] positive exploration of the new" (1978: 89). As may be clear, Vesely's emphasis on the exploration of the new as a surrealist strategy for overcoming the nihilism of Dada is not without its problems. The category of the new, as Bürger concludes, is both "too general and nonspecific" (1984: 63) and ties interpretation to a particular development of technical ability that is counterproductive in relationship to Dada and surrealism specifically, and art history at large. However, it is not just the dialectical relationship between old/new (Dada/surrealism) that is problematic but the attempt by Vesely to redeem surrealist practices in the name of the new. New architecture was subjected to continual ridicule by the surrealists, especially by Breton and Dali. Breton had famously listed contemporary architecture as the most ineffective of the creative practices and refers to modern architecture as "the most violent and cruel automatism" (1972: 259). ${ }^{12}$ At no point was this "a positive exploration of the new". If the theoretical discourse of surrealism and its associated artistic production were frequently misaligned, they operated in unison on this issue.

While Vesely is aware of this ancestry, what he considers the "exploration of the new" was in fact an exploration of the old because, as Vesely is also aware, it was historical and ruined architectures that became the primary inspiration for surrealism and the source of much of its imagery. However, there is also a deeper distinction that needs to be made and one that is critical to the relationship between architecture and the avant-garde. Although the strategies that are associated with the avant-garde are historically tied to the first decades of the twentieth century, they are distinct from the history of modernism and frequently a negation of modernism itself. ${ }^{13}$ The historical characteristics of modernism emerge in the wake of the Enlightenment and it is customary to associate the project of modernity (to employ Habermas's terminology) ${ }^{14}$ with a series of transformations that first began in the closing decades of the eighteenth century. The avant-garde, by contrast, occupies a much tighter historical focus and, more significantly, has its own internal historical forces that, while overlapping with the historical 
development of modernism, are essentially unique. ${ }^{15}$ In this regard, the emphasis that Bürger and Adorno place on negation is significant, defining the extent to which avant-garde practice is differentiated from modernism (Calinescu 1977: 140).

In architecture, in particular, there is evidence of an alternate consciousness to history outside of the hegemonic structures of academic scholarship, which reveals a deep-seated relationship to avant-garde practice. It is with this "historical consciousness" in mind that an expanded critical framework binding architecture and the historical avant-garde can be constructed. Despite being generally opposed to the inclusion of negation as a strategy of surrealism, ${ }^{16}$ Vesely does hint at the prospect of architecture operating as an objet trouvé in surrealist practice, shifting concerns away from the production of architectural form and towards the creative reappropriation of its fragments. It is this aspect of Vesely's historicisation of Dada and surrealism that, when framed in regard to Bürger's theorisation of the avant-gardist work of art, forms an important trajectory in architectural history particularly in regard to the mechanics of memory and discovery. Given this, the experimental period of Dada and surrealism that Vesely dismisses (1912-1924) is of primary importance, as it is in the discovery of the strategies of the readymade, collage, montage, drawing and photography, that the role of architecture becomes explicit as a central concern of avant-garde activity. Through the construction of highly-structured and deliberate spatial practices, surrealism developed a radicalised architecture to connect the visual and the lived. It is with an understanding of the importance of this transformation that the historical relationship between Dada, surrealism and architecture can be recast.
15 One of the primary limitations of Poggioli's theorising of the avant-garde is its inability to apply a more precise differentiation between the broad history of modernism and the narrow moment of the historical avant-garde. For a critique of this, see Jochen Schulte-Sasse's "Theory of modernism versus theory of the avant-garde" (1984: vii-xv).

16 Again dispelling the nihilism of Dada, Vesely argues that "Surrealism, unlike Dada, exploited the results of negation for its own positive goals, developing and cultivating the technique of surprise and bewilderment toward [the] surrealist crisis of the object" (1978: 91). 


\section{References}

Adorno, T. (1991). Looking back on surrealism (R. Tiedemann \& S. Weber Nicholsen, Trans.) In Notes to literature (pp. 86-90). New York, N. Y.: Columbia University Press.

Adorno, T. (1997). Aesthetic theory. (R. Hullot-Kentor, Trans.). Minneapolis: The Minnesota University Press.

Allison, J. (2010). The surreal house. New Haven, Ct: Yale University Press.

Baker, S. (2007). Surrealism, history, revolution. Bern: Peter Lang.

Benjamin, W. (1978). Reflections: Essays, aphorisms, autobiographical writings (E. Jephcott, Trans.). New York, N.Y.: Schocken Books.

Breton, A. (1978). What is surrealism?: Selected writings (F. Rosemount, Trans.). London, United Kingdom: Pluto Press.

Breton, A. (1987). Mad love [L'amour fou] (M. A. Caws, Trans). Nebraska: The University of Nebraska Press.

Breton, A. (1972). Manifestoes of surrealism (R. Seaver \& H. Lane, Trans.). Ann Arbor: University of Michigan.

Bürger, P. (1992). The decline of modernism. University Park: The Pennsylvania State University Press.

Bürger, P. (1971). Der französische Surrealismus: Studien zum Problem der avant-gardistischen Literatur. Frankfurt am Main: Athenaum.

Bürger, P. (1981). The significance of the avant-garde for contemporary aesthetics: A reply to Jurgen Habermas. (A. Huyssen and J. Zipes, Trans). New German critique, 22 (Winter), 19-22.

Bürger, P. (1985-1986). The institution of 'art' as a category in the sociology of literature. Cultural critique, 2 (Winter), 5-33.

Bürger, P. (1990). Aporias of modern aesthetics (B. Morgan, Trans.). New Left Review, 1 (184, November-December), 47-57.

Bürger, P. (2002). The thinking of the master: Bataille between Hegel and surrealism (R. Block, Trans). Evanston, III: Northwestern University Press.

Bürger, P. (1974). Theory of the avant-garde (M. Shaw, Trans.). Minneapolis: Minnesota Press.

Burns Gamard, E. (2000). Kurt Schwitters'Merzbau. New York, N.Y.: Princeton

Architectural Press.

Calinescu, M. (1977). Faces of modernity: Avant-garde, decadence, kitsch. Bloomington: Indiana University Press.

Dietrich, D. (1991). The fragment reframed: Kurt Schwitters' Merz-Column. Assemblage, 14 (April), 82-92.

Fanés, F. (2007). Salvador Dali: The construction of the image, 1925-1930. New Haven, Ct.: Yale University Press.

Foster, H. (1993). Compulsive beauty. Cambridge, Massachusetts: The MIT Press.

Foster, H. (2002a). The ABC of contemporary design. October, 100 (Spring), 191-199.

Foster, H. (2002b) Design and crime and other diatribes. London: Verso.

Frampton, K. (1978). Has the proletariat no use for a glider. Architectural design profile: Surrealism and architecture, 11, 2-3, 96-100.

Freud, S (1905). Three essays on the theory of sexuality. In Standard edition of the complete works of Sigmund Freud, 7 (J. Strachey, Trans.). London: Hogarth Press.

Fried, M. (1982). How modernism works: A response to T. J. Clark. Critical inquiry, 9 (September), 217-234.

Giedion, S. (1969). Mechanisation takes command: A contribution to anonymous history. New York, N.Y.: W. W. Norton Company.

Giedion, S. (1995). Building in France: Building in iron-building in ferro-concrete (J. Duncan Berry, Trans.). Los Angeles, Ca.: The Getty Centre for the Study of Art and the Humanities.

Gorlin, A. (1982). The ghost in the machine: Surrealism in the work of Le Corbusier. Perspecta, 18, 58-60.

Greenberg, C. (1971). Counter avant-garde. Art international, 15 (May), 16-19.

Habermas, J. (1981). Modernity versus postmodernity (S. Ben-Habib, Trans.). New German Critique, 22 (Winter), 3-14.

Habermas, J. (1975) Legitimation crisis (T. McCarthy, Trans). Boston, Mass.: Beacon Press. Harvey, D. (1990). The condition of postmodernity. London: Blackwell.

Hecht, B. (1987). Dadafest. In M. Gordon (Ed), Dada performance (80-81). New York, N.Y.: PAJ Publications. 
Heynen, H. (1999). What belongs to architecture? Avant-garde ideas in the modern movement. Journal of architecture, 4 (Summer), 143.

Huelsenbeck, R. (1987). A visit to the Cabaret Dada. In M. Gordon (Ed), Dada performance (pp. 83-85). New York, N.Y.: PAJ Publications.

Huyssen, A. (1986) After the great divide: Modernism, mass culture, postmodernism. Bloomington: Indiana University Press.

Krauss, R. (1981). Nightwalkers. Art journal, 41, 1, 33-34.

Krauss, R. (1994). The optical unconscious. Cambridge, Mass.: The MIT Press.

Macarthur, J. (2010). Schwitters and Benjamin: the modernity of the baroque and romanticism. The Journal of Architecture, 15, 3, 283-300.

Mertins, D. (1999). Walter Benjamin and the tectonic unconscious: Using architecture as an optical instrument. In A. Coles (Ed.), The optic of Walter Benjamin (pp. 196-221). London: Black Dog Publishing.

Mical, T. (Ed.). (2005). Surrealism and architecture. London: Routledge.

Osborne, P. (1989). Adorno and the metaphysics of modernism: The problem of a postmodern art. In A. Benjamin (Ed.), The problems of modernity: Adorno and Benjamin (pp. 23-48). London: Routledge.

Passerin d'Entrèves, M. \& Benhabib, S. (Eds.) (1997). Habermas and the unfinished project of modernity: Critical essays on the philosophical discourse of modernity. Cambridge, Mass.: The MIT Press.

Poggioli, R. (1968). The theory of the avant-garde. Cambridge, Mass.: Belknap Press.

Schulte-Sasse, J. (1984). Theory of modernism versus theory of the avant-garde. In P. Bürger, Theory of the avant-garde (vii-xv). Minneapolis: Minnesota Press.

Spiteri, R. (2009). Georges Bataille and the limits of modernism. Melbourne Art Journal, 4, 1-27. Sulieman, S. R. (1994). Bataille in the street: The search for virility in the 1930s. Critical Inquiry, 21(1), 61-79.

Vesely, D. (1978). Salvador Dali: On architecture. Architectural design profile: Surrealism and architecture, 11, 2-3,138.

Vesely, D. (2010). The surrealist house as a labyrinth and metaphor of creativity. In J. Allison (Ed.), The surreal house (pp. 34-41). New Haven, Ct.: Yale University Press.

Vidler, A. (1992). The architectural uncanny. Cambridge, Mass.: The MIT Press.

Vidler, A. (2003). Fantasy, the uncanny and surrealist theories of architecture. Papers of surrealism, 1 (Winter), 1-12. 